\title{
SOCIAL SECURITY AS PART OF THE NATIONAL SECURITY SYSTEM OF BULGARIA
}

\author{
Nikolay NICHEV, Associate Professor, PhD \\ Vasil Levski National Military University, Veliko Tarnovo, Bulgaria \\ nbnichev@nbu.bg
}

\begin{abstract}
Social security and social entrepreneurship are subject to special attention from the European Commission (EC), particularly in recent years. This is due to their potential to find solutions to society's problems related to the creation of sustainable jobs, facilitating social and occupational integration, provision of social services and improving the quality of life, including the fight against poverty and social exclusion. The current paper analyses the main strategic and policy documents supporting social security and social entrepreneurship development in Bulgaria.
\end{abstract}

Key words: social security, national security, social economy, entrepreneurship

\section{Introduction}

Social enterprises and social entrepreneurship are central to the agenda of the European Commission, in particular in its strategy „Europe 2020” strategy for „smart, sustainable and inclusive growth”. They are a key element of the European social model and contribute to the implementation of socially significant goals of the strategy. Their growing importance, especially in the context of the national security systems and the economic and financial crisis, is primarily the result of the need for Europeans for an ethical and social dimension to their work, consumption, 
savings and investment ${ }^{1}$. In recent years, the European Commission has begun setting a policy framework for the social economy and social entrepreneurship, which has found expression in a number of policy documents outlining the limits and opportunities for their development ${ }^{2}$.

Among the specific objectives set by „Europe 2020” are to provide $75 \%$ employment for groups of 20-60 year olds, reducing school drop-out by $10 \%$ and ensuring there are at least 20 million fewer people who are at risk of poverty or social exclusion. Social entrepreneurship is recognised as a measure for achieving these objectives as „a tool to achieve sustainable development". Analysis of social policies shows that reducing direct support reduces effectiveness, and the sustainability of the „successful” models remains reciprocal of inputs. This trend can only be stopped by promoting innovative social models that overcome unemployment, poverty and social exclusion permanently. Social benefits and services, promoting education, training and skills in various fields, improving access to public services such as measures of influence should be complemented by targeted efforts and resources to maintain the forms of socially vulnerable groups and would serve as a bridge to the primary labour market. A successful solution for achieving effective longterm results has recognised the role of social entrepreneurship.

Support and promotion of social enterprises can make the most of their growth potential and capacity to create added social value expressed through job creation, creative approaches to small business, new opportunities for social inclusion, and revenue for development activities of civic organisations ${ }^{4}$. The social economy plays an important role in the European Union, and its contribution can be illustrated as follows: over 2 million operating social enterprises in member states of the European Union; an employer of 11 million people, or nearly $6 \%$ of all employees; accelerated growth creating new social enterprises - 1 in 4 new companies are social enterprises.

1 Social enterprise and social entrepreneurship, Economic and Social Council of the Republic of Bulgaria, Sofia, 2013.

2 V. Terziev, N. Bencheva, E. Arabska, T. Stoeva, M. Tepavicharova, N. Nichev, Implications on Social Entrepreneurship Development in Bulgaria, Knowledge International Journal Scientific Papers, 1(13), Albania, 2016, pp. 203-208.

3 Encouragement and development of social enterprises in Bulgaria - Road map, 20152020.

4 Platform for social economy development in Bulgaria, Sofia, 2014. 
The following formulation is stressed: Social enterprises covering a wide range of businesses with different legal forms that provide social services or goods to vulnerable or marginalised persons. These services include access to housing, healthcare, assistance for elderly or disabled persons, child care, access to employment and training as well as dependency management. Social undertakings also include undertakings that employ a method of production of goods or services with a social objective, but whose activities may be outside the sphere of provision of social goods or services. Those activities include social and professional integration by means of access to employment for people disadvantaged in particular by insufficient qualifications or social or professional problems leading to exclusion and marginalisation.

\section{Strategies and Policies Encouraging Social Entrepreneurship}

In line with the strategy „Europe 2020”, the European Employment Strategy aims to create more and better jobs throughout the European Union (EU). In this respect, the strategy promotes measures for achieving three major objectives by 2020: a 75\% employment rate among people aged between 20 and 64 years; the share of early school leavers below $10 \%$ and completion of higher education by at least $40 \%$ of people aged between 30 and 34 years; at least 20 million fewer poor or at risk of poverty and social exclusion.

The actions referred to in the flagship initiative "Agenda for new skills and jobs” are essential for achieving these goals. Each year, national governments and European institutions prepare a 'package of measures in the field of employment ${ }^{5}$.

The strategic objectives in support of the Commission's response to unemployment and low levels of participation in the labour market in the EU with advanced and innovative policy ideas are: giving "new impetus to the combination of flexibility

5 Research Report about the status and reinforcement of social entrepreneurship in Europe. National Report - Bulgaria, Project SESBA: Social Enterprise Skills for Business Advisers, 2016. 
and security"6, involving all stakeholders in strengthening the elements of this combination and reinforcing controls on national agreements' combination of flexibility and security; self-employment.

Despite the rapid development of the social economy sector in the European Union and the growing role of social enterprises for combatting poverty and social exclusion, social entrepreneurship is almost imperceptible in Bulgaria ${ }^{7}$. Although still modest in the scale of social enterprises, Bulgaria has seen changing attitudes towards the so-called „welfare state” and allows for the mobilisation of additional resources in the social sector through development of entrepreneurial potential and innovation ${ }^{8}$.

In the implementation of „Europe 2020", each member state adopted its own reform strategy that identifies key national objectives and actions for achieving them within the common European ones. According to the National Reform Programme Bulgaria 2020, some of the main areas of structural reforms concern the modernisation of services for access to the labour market, to social support, health care and education. It is envisaged that the implementation of active employment measures will include members of vulnerable groups through mechanisms for ensuring sustainable employment, incentives for employers to find new jobs, programmes for training, re-training and acquiring key skills and so on. There are four priority areas: better infrastructure; competitive youth; a better business environment; greater confidence in state institutions. The programme will try to achieve a higher standard of living for citizens in Bulgaria to $60 \%$ of the EU average by 2020 .

The measures that need to be implemented in the short term and which are related to the social economy are:

- Development of a new Law on Children;

- Merging rules in the field of social economy in a statutory instrument;

6 V. Terziev, E. Arabska, Social Entrepreneurship in Europe, Vasil Levski National Military University, Artillery, Aircraft Defense and CIS Faculty, International Scientific Conference, 2016, Collection of Papers, pp. 401-408.

7 M. Tepavicharova, N. Bencheva, V. Terziev, T. Stoeva, E. Arabska, Social Entrepreneurship Encouragement in Bulgaria, International scientific conference Contemporary challenges to the security in Europe, Proceedings, pp. 312-333.

8 Platform for social economy development in Bulgaria, Sofia, 2014. 
- Development of a National concept of active ageing;

- Developing and implementing a mechanism for determining the minimum wage, taking into account economic and social functions;

- Support for the provision of modern social housing for vulnerable, minority and socially disadvantaged groups and other disadvantaged groups.

In the medium term, the following measures are included:

- Assessing the impact of policies and legislation related to material support to vulnerable groups;

- Investing in integrated services for early childhood development (for children from 0 to 7 );

- De-institutionalising child care (a network of social services in the community

- programmes leaving specialised institutions, foster care, etc.);

- Supporting families with children;

- Providing material support, appropriate forms of employment, training and re-training and an accessible environment for people with disabilities;

- Developing the social economy - creating new and supporting existing enterprises in the social economy;

- Increasing the adequacy of pensions;

- Creating a network of services for long-term care;

- Constructing social housing, including the most vulnerable members of the Roma community;

- Creating integrated social, health and educational services for homeless people;

- Carrying out a study on homelessness, creating a statistical database on homelessness and its dimensions and developing a comprehensive strategy for combating homelessness.

It follows that the objectives of the National Programme are directly related to the social economy and improving the status of vulnerable groups in society 9 Measures will be taken for development of the social economy and the creation of

9 M.M. Brutyan, M.P. Vahromeeva, T.M. Vorozheykina, S.S. Chernova, Problemay Sovremennoy Ekonomiki, Novosibirsk, 2016, pp. 183-260. 
new and support existing enterprises in the social economy on the development of social entrepreneurship in Bulgaria ${ }^{10}$.

In 2011, the Bulgarian government adopted a policy document - „National concept of social economy"11, which represents the vision and priorities for the promotion and development of the social economy in the country. This concept reflects the social commitment of the State to establishing and strengthening an enabling environment for the implementation and development of models and practices in the field of social economy in Bulgaria. The social economy is perceived simultaneously as part of the real economy and civil society, in which individuals and/or legal persons, associations of volunteers or other organised entities doing business in the public interest and re-investing profits to achieve social goals ${ }^{12}$.

The national concept of social economy is an expression of the social commitment of the State to establish and strengthen an enabling environment for the implementation and development of models and practices in the field of social economy and national security in Bulgaria. It is an expression of intention and determination to promote awareness, culture and values related to companies and organisations in the social economy. National Concept is a document which presents the vision and priorities for promoting the development of social economy in the country. It represents the active position of the state formed as a result of the joint efforts of a wide range of stakeholders. As a result of activity on the formation of a national position on the social economy and social security, the National concept is expected to be developed along with policies that lead to the improved quality of life and well-being of vulnerable groups in society. A resistant sector is expected to be formed to help overcome the social exclusion of groups of

10 V. Terziev, E. Arabska, Needs and Challenges of Social Entrepreneurs, First SESBA Conference Tips, skills \& tools for consulting social entrepreneurs, Agricultural University, Plovdiv, 2016, pp. 51-60.

11 V. Terziev, E. Arabska, Social Enterprises and Social Entrepreneurs, Artillery, Aircraft Defense and CIS Faculty, International Scientific Conference, 2016, Collection of Papers, pp. 409-416.

12 V. Terziev, E. Arabska, Social Entrepreneurship Development in Bulgaria, [in:] The effectiveness of business management: investments and innovation, Collective monograph, - AMEET Sp. z o.o., Łódz, Poland, pp. 4-107. 
people with disabilities. Changes are expected to include a wide range of people in society who find it difficult to access jobs, services and resources ${ }^{13}$.

National Concept relies on an understanding of the social economy, reflected in the documents of the European Union and other international documents. It is in line with national strategic documents which are directly or indirectly related to the tasks arising from defined concept purposes. This document is a contribution to the objectives of "Europe 2020" - a strategy for smart, sustainable and inclusive growth that offers a vision of the social market economy of Europe for the 21st century. The strategy that economic realities evolve faster than the political concept specifies ripe processes of the real economy, which should delineate the private sector development to become visible as a government policy context for raising the standard of living, is committed to the social situation of marginalised groups in the labour market.

National Concept provides a proactive vision for future changes in legislation and the practice of state authorities and a vision for the integration of sectoral security policies. It is a document that develops an approach based on the best national and international practices in this area, classified and analysed under an interagency working group of experts with the broad participation of representatives of state and international institutions, social partner organisations, and NGOs.

The state seeks to create a harmonious society by promoting the development of social economy in the country to achieve stability, economic growth and quality of life, especially of disadvantaged groups. Establishment of a favourable environment for the social economy sector is achieved through adequate policies and partnerships at international, national, regional and local level. All interested parties are actively involved in this process.

The vision of the concept is: a validated developed social economy sector, which extends the conditions for the active inclusion of vulnerable groups in society and achieves flexibility and security in employment and develops territorial cohesion.

13 V. Terziev, E. Arabska, Social Enterprises and Social Entrepreneurs, Artillery, Aircraft Defense and CIS Faculty, International Scientific Conference, 2016, Collection of Papers, pp. 409-416. 
In the process of strengthening the model of social economy, the state plays an active role in promoting, encouraging and supporting the introduction of successful practices of social enterprises, including on the basis of voluntary activities developed within civil society. To make these commitments, the country creates an enabling legal and institutional environment and coordinated sectoral policies for accelerated introduction into the practice of successful models of social enterprises. In so doing, the government will implement measures to increase the productivity and competitiveness of these enterprises and will monitor the correct acquisition and adherence to the brand "Product of the social enterprise."

A prerequisite in developing the concept is to reach a common agreement within the wide range of stakeholders on key issues related to the nature, scope, limits and potential in terms of the national security of the social economy in the country to achieve better opportunities for the social inclusion of disadvantaged groups; pooling resources to increase employment among social groups with limited access to services and resources or outside the labour market; development of local and territorial cohesion.

The concept has the following specific objectives:

1. To serve as a reference for setting criteria for identification of enterprises and organisations of the social economy;

2. To serve as a current 'standard' in helping to support the development of social economy and stimulate artists and supporters to apply and disseminate the spirit of social solidarity;

3. To serve as a basis for creation of a favourable administrative and legal environment for the development of social economy enterprises (access to finance, social clauses in public contracts, tax breaks, etc.).

The development and promotion of a sustainable social economy sector, and through it and the national security system in the Bulgaria, will be achieved by implementing the guiding principles of good governance and the specific principles relating to the implementation of best practices and models of social enterprises. Specific principles on which the best practices and models of social economy enterprises can be built are related to ensuring unity between economic efficiency and the specific social objectives, developing activities in terms of public transparency and implementing solidarity principles of internal management and decision-making. 
The state introduces the "A product of a social enterprise" brand in a logo and a procedure for awarding entities, the results of which correspond to the indicators set out in this Concept. The brand allows the awarded enterprise to designate goods from its product specification, manufacturing and commercial space objects, documents, advertisements, clothing production and others. The purpose of the appropriation of the brand and its application is to attract public attention to the cause for which such businesses operate, in order to attract the involvement of the mass consumer of consumer goods and services in the form of preferred purchases of preferred retail outlets.

The implementation of the concept of social economy will be implemented through a package of measures included in the annual implementation plans. The activities envisaged in the implementation of the measures are in line with the concept and are coordinated joint actions of stakeholders. Some of them are executed independently by public institutions and others - together with stakeholders from NGOs, social partners, employers' associations and others. The plan identifies the leading state institutions, defined in terms of their competence. There are deadlines for implementing the activities and sources of funding. Plans are approved by the National Council for Tripartite Cooperation, then adopted by the Council of Ministers. The aim of the Action Plan on Social Economy for 2016-2017 is the development and promotion of the social economy and entrepreneurship ${ }^{14}$. The plan set out a number of awareness campaigns and forums to raise the visibility of social enterprises in Bulgaria and present the best practices in this field. The strategic document foresees the development of a methodology for assessing the social impact of social enterprises to raise living standards. It will introduce instruments for the surveillance and monitoring of the contribution of social enterprises to improving the quality of life. It is planned to conduct an annual European Forum on social enterprises. MLSP will continue to organise the annual national awards for social innovation.

In the Operational Programme „Human Resources Development” ${ }^{\prime 15}$ (2014-2020) the social economy and social entrepreneurship are displayed as a separate investment priority, thus further emphasising the contribution of initiatives and

14 Ministry of labour and social policy of the Republic of Bulgaria.

15 Human Resources Development Operational Programme. 
measures that will increase opportunities for consolidating the social sector economy.

Information exchange between the various levels is needed and should be implemented within the standard procedural requirements. In order to provide more visibility and awareness, information days and campaigns, and training to promote the ideas of social economy should take place. Maintaining a forum on the concept site can provide additional results in the distribution and adoption of the concept.

In connection with the development and improvement of the concept, the immediate tasks facing the government are: to execute the concept so as to institutionalise its implementation; to establish criteria for access to the government's measures for enterprises and social economy organisations; propose legislative changes aimed at improving the favourable legal and administrative environment for social economy enterprises, taking into account the views of all stakeholders; to promote measures enabling statistical reporting of the social economy.

Within the National Concept, the social enterprise is defined as a basic economic unit of the social economy, which stands between the private and public sectors. Activities carried out by social enterprises include: promoting employment opportunities and career development of people without jobs, people with disabilities and other vulnerable persons, as well as assistance in finding or returning to work; promoting opportunities for self-employment, entrepreneurship, and starting your own business.

The objectives of the concept are to introduce criteria for identification of enterprises and organisations of the social economy and serve as a basis for creating a favourable environment for the development of social enterprises ${ }^{16}$.

Although the Bulgarian legislation includes no definition of social enterprise, and rules governing the status, form and operation of social enterprises in real life and practice, there are many examples of functional social enterprises, which,

16 V. Terziev, E. Arabska, R. Dimitrovski, L. Pushova, Challenges to Social Entrepreneurship Development in Bulgaria, Knowledge International Journal Scientific Papers, 1(15), 2016, pp. 517-525. 
on the one hand, pursue social objectives and apply economic mechanisms and market principles in their operations ${ }^{17}$. Dynamic processes of social and economic development in recent years have clearly shown the following trends that reinforce the role and importance of the social economy in Bulgaria ${ }^{18}$ : the inability of the state to deal with the growing social needs of the population and a growing population in need of support; the debunked myth about the capabilities of the market economy to solve all social problems through the application of market principles; strengthening the role of local communities and civil society organisations in the process of the development and provision of innovative social support services to the most vulnerable part of the population.

Reforms are needed and innovative measures aimed at developing new approaches and models to tackle poverty and social exclusion ${ }^{19}$. The social economy and entrepreneurship is one of the key instruments through which the national security government policy can be complemented at a time of social support and smart and sustainable growth ${ }^{20}$.

There is no comprehensive and systematic policy to promote the social economy, including the legal framework and financing, as well as specific sustainable measures for launching and supporting social enterprises and creating an environment conducive to the development of social economy ${ }^{21}$.

Tracking the available practice of recent years in Bulgaria gives grounds to conclude that the entities operating in the social economy sector receive an incentive for development when there are national targeted programmes for their assistance,

17 V. Terziev, E. Arabska, R. Dimitrovski, L. Pushova, Conceptual and Normative Basis for Developmnet of Social Entrepreneurship, Knowledge International Journal Scientific Papers, 1(15), 2016, pp. 527-536.

18 V. Terziev, N. Bencheva, E. Arabska, T. Stoeva, M. Tepavicharova, N. Nichev, Facts and Figures on Social Enterprises in Bulgaria, Knowledge International Journal Scientific Papers, 1(13), Albania, 2016, pp. 183-188.

19 V. Terziev, N. Bencheva, E. Arabska, T. Stoeva, M. Tepavicharova, N. Nichev, Social Entrepreneurship in Bulgaria: Barriers to Growth, Knowledge International Journal Scientific Papers, 1(13), Albania, 2016, pp. 197-202.

20 V. Terziev, N. Bencheva, E. Arabska, T. Stoeva, M. Tepavicharova, N. Nichev, Implications on Social Entrepreneurship Development in Bulgaria, Knowledge International Journal Scientific Papers, 1(13), Albania, 2016, pp. 203-208.

21 V. Terziev, N. Bencheva, E. Arabska, Implications on Development of Social Economy in Bulgaria, Scientific Journal Economics and Finance, pp. 55-63. 
financing and development ${ }^{22}$. It still lacks the recognition of social enterprises as an innovative model for employment of disadvantaged groups in the labour market, as well as a new form for active social inclusion. It is important to define the areas and policies where the possibilities of social enterprises are still highly undervalued and unused ${ }^{23}$.

\section{Combating Poverty and Social Exclusion}

According to the National Strategy for Combating Poverty and Social Exclusion 2020, a lack of employment is one of the main causes of poverty and social exclusion. Therefore, the priority is to promote the active inclusion of those furthest from the labour market - economically inactive young people, long-term unemployed, people on social assistance, with primary or lower education and no professional qualifications or lack of key competencies among people with permanent disabilities, elderly workers and others. Through the development of viable social enterprises, access to employment and support for the social inclusion of vulnerable groups can be provided by creating appropriate conditions for their professional integration into the social economy.

In addition, social enterprises can be a key tool for implementing the European strategy for employment, as they combine measures for enhancing access to the labour market, supporting social services and the provision of adequate income and, thus, contribute to prevention of the transmission of poverty between generations ${ }^{24}$. Although it is important to provide services that help people to "enter" the labour market, it is equally important that people with complex needs integrate into society, even if it is difficult to provide them with employment opportunities. Despite the potential for poverty reduction and inclusion in the

22 V. Terziev, N. Bencheva, E. Arabska, T. Stoeva, Insight Into the Social Entrepreneurship in Bulgaria, Yearbook of Bishop Konstantin Preslavski University of Shumen, XXD, pp. 153-160.

23 V. Terziev, N. Bencheva, E. Arabska, T. Stoeva, Innovations in the Public Policies in Bulgaria, Yearbook of Bishop Konstantin Preslavski University of Shumen, XXD, pp. 132-152.

24 V. Terziev, N. Bencheva, T. Stoeva, E. Arabska, Social Enterprises in Bulgaria, Scientific Journal Economics and Finance, pp. 63-74. 
labour market of long-term unemployed and inactive persons, it is difficult to discern the level of policies and programmes of social enterprises and, thus, they remain undervalued and underutilised. The huge deficit in this area includes organisations that can provide the integrated services necessary for the social inclusion of people furthest from the labour market groups with an emphasis on social skills and improving individual social work with these individuals ${ }^{25}$.

\section{Youth Employment}

A major priority for the Commission is to combat youth unemployment and each EU member state has taken concrete political commitments for implementing the European Youth Guarantee. The National Plan of Bulgaria foresees the implementation of measures to support job creation for hiring unemployed youths and subsidising temporary employment for youth from regions where unemployment is high and the economic infrastructure is poorly developed. Social enterprises can be supported by employers who hire young people for temporary work in Public Works, thereby acting as a tool for sustainable integration of young people into the labour market through a combination of temporary employment by providing incentives and training opportunities.

National Strategy for the youth 2010-2020 adopted by the Council of Ministers aims to create a suitable and favourable environment and conditions for school and university education as well as the active participation of young people in social and economic life. The strategic objective is improved economic activity and career development of young people. Part of this goal is the promotion of social entrepreneurship among young people. To achieve the objective, promoting and supporting public-private partnerships and social entrepreneurship in providing services for the development of young people is necessary.

Young people should not only be supported by social entrepreneurship, but also understand more about its effect and importance.

25 V. Terziev, N. Bencheva, M. Tepavicharova, E. Arabska, Encouragement of Social Entrepreneurship in Bulgaria, Scientific Journal Economics and Finance, pp. 45-55. 


\section{Equal Access to Participation in the Economy of the Population in Small Towns / Rural Areas}

Since over $70 \%$ of Bulgaria's territory is in rural areas,opportunities for the development of social enterprises in small towns should be defined. Traditionally, these regions experience low quality and limited availability of public services, lack of social, educational and health services, as well as enhanced processes of de-population and lack of employment opportunities and income. With these characteristics, rural areas provide an excellent opportunity for social enterprises to offer innovative methods to fill existing market niches, while providing access to resources through local action groups and the implementation of the new instrument of the EC for community-led local development. In the partnership agreement of the Republic of Bulgaria with the European Commission for the period 2014 - 2020, the outlining aid from European structural and investment funds clearly defines the role of this development as a useful tool for the empowerment of local communities, including disadvantaged groups, improving the institutional capacity of local stakeholders, and particularly NGOs, and the creation of social innovation at the local level. In this context, this development will promote the development of social economy and social enterprises in rural areas.

\section{Social Innovation}

In connection with the social economy, leading initiatives related to innovation, particularly in terms of contribution to social enterprises for social innovation are of particular interest; those related to the creation of new skills for new jobs and the European platform against poverty. The creation in 2013 of the European Union Programme for Employment and Social Innovation (EU Regulation 1296/2013 of the European Parliament) makes it possible to provide targeted funding to social enterprises that have an enormous capacity for social innovation and generate social capital. 


\section{Integration of Minorities}

Social enterprises are a key model for the effective implementation of the priority of creating employment for minorities, clearly outlined in the National Strategy for Roma integration by 2020 . The role of social enterprises to promote employment in green jobs by subsidising jobs in environmental activities and the creation of quality employment and environmental protection is underestimated. Another major opportunity for implementing the model of social enterprises is to promote entrepreneurship, for Roma starting and managing their own businesses taking full advantage of the skills and traditions of the Roma in order to generate income.

Action Plan „Entrepreneurship 2020 - Bulgaria” was adopted by Protocol №46 of November 11, 2015 by the Council of Ministers with a concrete 31 measures in accordance with those adopted by the Commission - Action Plan „Entrepreneurship 2020 - Revival of the entrepreneurial spirit in Europe „(COM / 2012/0795 final). With the adoption of the Action Plan „Entrepreneurship 2020 Bulgaria" and proposed measures to implement the recommendations of the Commission by 2020, the country is committed in the long term by the Ministry of Economy policy to promote and create new businesses. The measures of the Action Plan for Entrepreneurship 2020 - Bulgaria:

Field of action №1 - „Education and training in entrepreneurship to support growth and new business creation." This includes 15 measures. They are related to the introduction of programmes for the formation of entrepreneurial skills in schools, updating entrepreneurship programmes in vocational education, universities, secondary schools, promoting entrepreneurship among young people, training of entrepreneurs in the field of agriculture and forestry etc.

Field of action №2 - „Better administrative and legislative environment for entrepreneurs and support the crucial stage of the life cycle." This includes 10 measures. They are connected with programmes to fund start-up entrepreneurs - young farmers in agriculture, support for pilot projects to develop new products through clusters in agriculture, support for start-up entrepreneurs students, support the growth of businesses by promoting the use of ICT and support through financial instruments. This field includes a measure to reduce the time needed to get licenses and permits. 
Field of action №3 - „Strengthening the entrepreneurial culture in Europe for the growth of a new generation of entrepreneurs." This includes 6 measures. They are related to encouraging and promoting entrepreneurship in Bulgaria, developing a strategy to promote women's entrepreneurship, supporting a network of women entrepreneurs, support for the employment of people who care for children and other dependent family members, establishing a mechanism for exchange of experience and skills of older entrepreneurs to new entrepreneurs and promoting entrepreneurship for unemployed young people under 29 years.

\section{Conclusions}

Social entrepreneurship is one of the most innovative ways for persons from vulnerable groups to achieve a better quality of life, independence and inclusion in society. There is a clear need for key legislative changes to be taken in Bulgaria in order set measures in strategic and political national documents to become real mechanisms to support social entrepreneurship in Bulgaria, as well as the successful development of social enterprises, which also requires the creation of sustainable partnerships between business, NGOs and the public sector partnerships in which each of these actors recognises its role in achieving socially important objectives and is willing to invest resources in this.

The national policy for the development of social economy and social enterprises stands aloof from the common efforts to achieve the objectives of the Strategy for National Security of Republic of Bulgaria ${ }^{26}$. Although the Strategy for National Security has been prepared as a strategic document with „anticipatory vision for future changes in legislation and the practice of state authorities and vision for the integration of sectoral policies", the still relevant sectoral policies are not clearly and consistently bound by it. This prevents the creation of a favourable legal and financial environment for the development of social security as a part of the national security system in Bulgaria.

26 Strategy for National Security of Republic of Bulgaria. 


\section{Bibliography}

Action Plan „Entrepreneurship 2020 - Bulgaria”.

Action Plan "Entrepreneurship 2020 - Revival of the entrepreneurial spirit in Europe” (COM / 2012/0795 final).

Agenda for new skills and jobs: http://ec.europa.eu/social/main.jsp?catId=1223/.

Employment Strategy of the Republic of Bulgaria 2012-2020.

Encouragement and Development of Social Enterprises in Bulgaria - Road Map 20152020.

Strategy for National Security of Republic of Bulgaria

Strategy: http://ec.europa.eu/europe2020/index_en.htm/.

European Employment Strategy: http://ec.europa.eu/social/main. jsp?catId=101\&langId=en $/$.

European Union Programme for Employment and Social Innovation (EU Regulation 1296/2013 of the European Parliament).

Human Resources Development Operational Programme.

Long-term Strategy for Employment of People with Disabilities 2011-2020.

Ministry of Labour and Social Policy of the Republic of Bulgaria: http://www.mlsp. government.bg/.

National Concept of Social Economy, Sofia, 2011.

National Reform Program Bulgaria 2020.

National Strategy for Combating Poverty and Social Exclusion 2020.

National Strategy for Roma integration by 2020.

National Strategy for the youth 2010-2020.

National strategy to reduce poverty and promote social inclusion (2020).

Platform for Social Economy Development in Bulgaria, Sofia, 2014: http://pgf.osi.bg/data/file/ Documents/Platform\%20Social\%20Economy\%20BG\%20MERI\%20EUROCITIES.pdf/.

Brutyan M. M., Vahromeeva M. P., Vorozheykina T. M., Chernova S. S., Problemay Sovremennoy Ekonomiki: monografiya - Research report about the status and reinforcement of social entrepreneurship in Europe, Novosibirsk, 2016.

Research Report about the Status and Reinforcement of Social Entrepreneurship in Europe.

National Report - Bulgaria, Project SESBA: Social Enterprise Skills for Business Advisers, 2016, http://sesbaproject.eu/en/research/.

Social Enterprise and Social Entrepreneurship, Economic and Social Council of the Republic of Bulgaria, Sofia, 2013.

Tepavicharova M., Bencheva N., Terziev V., Stoeva T., Arabska E., Social Entrepreneurship Encouragement in Bulgaria, International scientific conference Contemporary challenges to the security in Europe, Proceedings, 2016.

Terziev V., Arabska E., Needs and Challenges of Social Entrepreneurs, First SESBA Conference Tips, skills \& tools for consulting social entrepreneurs, Agricultural 
University - Plovdiv, Project SESBA: Social Enterprise Skills for Business Advisers No 2015-1-EL01-KA202-014097 Erasmus+, Bulgaria, 2016.

Terziev V., Arabska E., Social Entrepreneurship Development in Bulgaria, [in:] The

effectiveness of business management: investments and innovation, Łódź, 2016.

Terziev V., Arabska E., Social Enterprises and Social Entrepreneurs, Artillery, Aircraft

Defense and CIS Faculty, International Scientific Conference, Shumen, Bulgaria, 2016.

Terziev V., Arabska E., Social Entrepreneurship in Europe, Vasil Levski National Military

University, Artillery, Aircraft Defense and CIS Faculty, International Scientific

Conference, Shumen, Bulgaria, 2016.

Terziev V., Arabska E., Impact of Social Enterprises, Artillery, Aircraft Defense and CIS

Faculty, International Scientific Conference, Papers, Shumen, Bulgaria, 2016.

Terziev V., Arabska E., Dimitrovski R., Pushova L., Challenges to Social Entrepreneurship

Development in Bulgaria, Bansko, Bulgaria, Knowledge International Journal Scientific Papers, 1(15), 2016.

Terziev V., Arabska E., Dimitrovski R., Pushova L., Conceptual and Normative Basis for

Developmnet of Social Entrepreneurship, Bansko, Bulgaria, Knowledge International Journal - Scientific papers, 1(15), 2016.

Terziev V., Bencheva N., Arabska E., Stoeva T., Tepavicharova M., Nichev N., Facts and

Figures on Social Enterprises in Bulgaria, Knowledge International Journal Scientific Papers, 1(13), 2016.

Terziev V., Bencheva N., Arabska E., Stoeva T., Tepavicharova M., Nichev N., Social

Entrepreneurship in Bulgaria: Barriers to Growth, Knowledge International Journal Scientific Papers, 1(13), 2016.

Terziev V., Bencheva N., Arabska E., Stoeva T., Tepavicharova M., Nichev N., Implications on Social Entrepreneurship Development in Bulgaria, Knowledge International Journal Scientific Papers, 1(13), 2016.

Terziev V., Bencheva N., Arabska E., Implications on Development of Social Economy in Bulgaria, Scientific Journal Economics and Finance, 2016.

Terziev V., Bencheva N., Arabska E., Stoeva T., Innovations in the Public Policies in Bulgaria, Yearbook of Bishop Konstantin Preslavski University of Shumen, XXD, Bulgaria, 2016.

Terziev V., Bencheva N., Arabska E., Stoeva T., Insight into the Social Entrepreneurship in Bulgaria, Yearbook of Bishop Konstantin Preslavski University of Shumen, XXD, Bulgaria, 2016.

Terziev V., Bencheva N., Stoeva T., Arabska E., Social Enterprises in Bulgaria, Scientific Journal Economics and Finance, 2016.

Terziev V., Bencheva N., Tepavicharova M., Arabska E., Encouragement of social entrepreneurship in Bulgaria, Scientific Journal Economics and Finance, 2016. 